\title{
Adult Learning and Doctoral Student Research Forum Participation: Insights into the Nature of Professional Participatory Experience
}

\author{
Joellen E. Coryell and Kayon Murray \\ Texas State University, San Marcos, Texas, USA \\ Coryell@txstate.edu Kkm56@txstate.edu
}

\begin{abstract}
Few research studies have focused on student learning as conference participants. Framed by situated cognition and informal learning theories, this qualitative study investigated how participation in a uniquely designed, international doctoral forum may have played a role in students' educational development as scholars. Findings indicate that participation in the forum had positive influences on doctoral student learning and development including enhanced understandings of the research process and the larger professional community of scholarly practice as well as increased confidence and motivation regarding students' own dissertation studies and identities as developing researchers. The paper concludes with suggestions for designing the kinds of forums and experiences that might simultaneously extend pedagogic practice and support doctoral student development. Recommendations for further research are also discussed.
\end{abstract}

Keywords: doctoral student development, learning at conferences, researcher development, community of practice, adult learning; doctoral student research forums

\section{Introduction}

Doctoral study in educational disciplines is designed to equip students with the concepts and skills necessary to become effective educational researchers. The teaching of educational research occurs in various methodology courses students are required to take, but students learn about research in a variety of ways, through collaboration on research projects and through conducting their own research. Training in research methods in graduate programs can vary widely and is influenced by a number of individual, departmental, and institutional factors (Astramovich, Okech, \& Hoskins, 2004). We also know that doctoral students enter their programs with a variety of background experiences, motivations, ranges of academic and social situations, and capacities for teaching, research, and scholarly productivity, which result in varying developmental progression rates (Nettles \& Millett, 2006). Knowing that not all learners learn and develop in the

Material published as part of this publication, either on-line or in print, is copyrighted by the Informing Science Institute. Permission to make digital or paper copy of part or all of these works for personal or classroom use is granted without fee provided that the copies are not made or distributed for profit or commercial advantage AND that copies 1) bear this notice in full and 2) give the full citation on the first page. It is permissible to abstract these works so long as credit is given. To copy in all other cases or to republish or to post on a server or to redistribute to lists requires specific permission and payment of a fee. Contact Publisher@InformingScience.org to request redistribution permission. same way, faculty, and students, alike, call for continued investigation into best practices for preparation and training of doctoral student researchers (DragoSeverson, Asghar, \& Gaylor, 2003; Young, 2001).

One way to attend to the needs of developing researchers may be the collaborative experiences offered at research conferences or forums. The objective of this 
study was to discover how participation in such an event may have played a role in student participants' educational development as scholars. The format of the event was unique when compared with many other research conferences. It was designed specifically so that U.S. and international doctoral students in education could come together at a pre-conference before an international academic and professional convention in their field. The eight-hour 'Doctoral Student Forum' invited doctoral students to submit proposals for presenting their research at varying stages of the dissertation process in poster sessions, as well as to connect with each other and other academics and professionals from a variety of institutions to discuss doctoral research. There were a series of three poster presentations that all participants attended throughout the day; a student would present at one of the poster sessions and be a part of the poster audiences in dialogue during the other two sessions. In addition, the forum invited 8-10 professors and professionals from national and international educational institutions to participate in the discussions and mentoring roundtable meetings in between poster sessions. Although not all of the student participants at the forum presented at the forum, the vast majority did. Framed through situated cognition, the concept of communities of practice (Lave \& Wenger, 1991), and informal learning theories our research questions were (1) in what ways does participating in this research forum impact learners' understanding of research and the community of scholarly practice? and (2) what is the nature of participatory learning for doctoral students who engage in such an event?

\section{Review of Literature and Theoretical Framework}

Literature in adult higher education calls for more investigation into the influences on adult learning in higher education in general (i.e., Donaldson, Flannery, \& Ross-Gordon, 1993; Graham \& Donaldson, 1999; Graham, Donaldson, Kasworm, \& Dirkx, 2000; Kasworm, 2003; O’Donnell \& Tobell, 2007) and on adult learning in doctoral programs in specifically (Drago-Severson et al., 2003; Young, 2001). This is particularly necessary because of the diverse nature of doctoral student populations and programs (Nettles \& Millett, 2006) and the complex range of individual, departmental, and institutional factors that shape doctoral students' learning (Astramovich et al., 2004). Investigating the experiences of adult learners in these programs, as well as about students' meaning-making processes in formal and informal program-related experiences, are warranted if we are to shape effective curricula and educative paths that support learners appropriately.

Drago-Severson et al. (2003) suggest that the developmental capacities of doctoral students may vary in ways that affect what preparation they will need to become expert researchers. Doctoral students must become familiar with a variety of research methodologies, discover and master a large body of knowledge and practices through extensive literature reviews, develop data gathering abilities, acquire specific technological skills (i.e., statistical procedures, qualitative analyses and archival categorization software), and cultivate the craft and experiential elements of analytical writing (Hockey \& Allen-Collinson, 2005). Kegan (1994) suggests that students can make better sense of their learning if they engage in courses that provide support throughout the learning process, allow for individual growth, and provide continuity and availability throughout the program.

In the study of teaching and learning, what counts as knowledge, as evidence of an assertion, and as merit of that evidence is abstract and diverse (Pallas, 2001). Developing researchers are constantly questioning, examining, and re-examining their thought processes as individuals and as researchers (Mittapalli \& Samaras, 2008). In addition, Parsons and McRae (2007) contend that doing research is more than simply gathering data to support educational change; it is actually "a theory of knowledge construction, a discourse-creating act, and thus a site for the contestation of power" (p. 2). Ultimately, the range and assortment of beliefs about what is valued in educational research can be overwhelming for the inexperienced investigator. 
In fact, students often experience identity construction, modification, and maintenance as they wrestle with combining a variety of research and practice roles (Gardner, 2009; Hockey \& AllenCollinson, 2005; Renner, 2001) and learn about becoming a producer of knowledge (Green, 2005). Jorgensen (1989) asserts that developing as a researcher requires individuals to sort-out roles of participation, while Roberts and McGinty (1995) advise learners to be aware of their feelings, perceptions, and actions in context with their personal biographies in the learning process. As such, doctoral students may experience anxiety in their programs due to feelings of inadequacy and intimidation during the research process (Coryell, Clark, Wagner, \& Stuessy, 2013). However, Borg (2001) argues,

We rarely hear about the emotional side of doing research, and the implicit message researchers may derive from this silence is that emotions have no role to play in their work and perhaps even that these should be denied and suppressed. Emotions, though, are an undeniable part of the human researcher's work. (p. 164)

Wright (2008) adds that research decisions can be influenced by the researcher's political, economic, and social life contexts and that embodied knowing, intellectual obsessions, and class orientation can significantly influence researcher self-development.

\section{Doctoral Student Researcher Development}

Although space constraints preclude a full description here, the literature on doctoral student development offers a variety of models outlining phases or stages of knowledge construction, socialization, and professionalization (e.g., Gardner, 2009; Grover, 2007; Lovitts, 2001; Stewart, 1995; Weidman, Twale \& Stein, 2001). Ultimately, developing a professional researcher identity in doctoral studies can be fraught with challenges, and specific support may be necessary for students' success in these programs. Developing a professional identity requires socialization processes in which individuals accept and assume the skills, knowledge, attitudes, values, beliefs, habits of mind, and norms of the profession (Gardner, 2009; Merton, 1957). The socialization that occurs in graduate school is multifaceted as students are simultaneously socialized into the academic program and department, into graduate student life, and ultimately in preparatory socialization experiences into the future career (Golde, 1998).

Most studies seem to concur with Weidman, Twale, and Stein's (2001) finding that doctoral students are as concerned about personal and relational components of the path to professional researcher identity as they are about coursework. Stevens-Long, Shapiro, and McClintock (2012) assert that compared to traditional classroom-based adult learning, transformative learning experiences occurred in the context of interactive and diverse mentorship relationships, forums, and learning groups (faculty to student and student to student). As such, participants emphasized learning outside the classroom was particularly meaningful through "community support, faculty as colleagues and bonding with students" (Stevens-Long et al., p. 192). In addition, these learning outcomes include more than just cognitive or intellectual development. Indeed, new dimensions and aptitudes related to emotional experience, self-conception, and reflective practice are also found in the doctoral student development literature. Leshem (2007) found that different levels of informal interactions in doctoral cohort communities aided in learners' developing understanding of conceptual frameworks in research, and Lahenius (2012) found that student communities of practice outside the classroom can support students' learning in doctoral studies. Stevens-Long et al. (2012) add:

The close relationships and interactive learning process described by many of the respondents may provide a supportive context for both the disorientation brought on by new experiences and perspectives, and the dialogue and discourse through which broad and deep learning outcomes occur. (p. 193) 
Austin (2002) found that doctoral students located meaningful learning through interactions in faculty-apprentice relationships. She also noted high levels of reliance that students placed on their peers to make sense of their experiences in graduate school. As such, one of the strongest recommendations by participants in the study was the need for structured opportunities to observe, meet, and talk with peers. Explaining that graduate students value peer interaction outside the regular classroom for both the social value and information shared, she noted that a lack of systematic professional opportunities and feedback was cause for concern. In light of this, many doctoral students are generally concerned about relationship building with both faculty and students to alleviate feelings of isolation and to ensure progress toward doctoral researcher identity (Gardner, 2009).

\section{Learning in Research Conferences}

In combining insights from science research and sociocultural theory over time, Jacobs and McFarlane (2005) asserted that conferences may be conceptualized as

1. The formal presentation of recent developments in the field.

2. The community evaluation of those developments (both substantive and methodological).

3. The informal presentation of other relevant developments from the community, e.g., from the conference floor.

4. Discussion of the interpretations and implications of those developments.

5. Settling disagreements over these interpretations and implications.

6. Doing 1-5 according to the practical organization of a reflective community of practice.

7. Inducting inexperienced members into the community of practice by making aspects of practice explicit and therefore capable of being apprehended.

8. Ensuring that, as a whole, research and/or professional practice progresses both substantively and methodologically. (p. 319)

As such, they contended that conferences offer significant opportunities for learning that include the possibility for novices to interact with more experienced professionals in a given field and also to take part in "the business of being a professional researcher" (p. 319). However, although conference participants generally include researchers, practitioners, and students (Hilliard, 2006), only a few research studies have focused on what and how these participants learn while in attendance (Chapman et al., 2009; Hilliard, 2006; Rose, 1992). As such, in 1992 Rose called for more scholarly investigations in this area while suggesting that conference attendees could be divided into three participant categories: those who do not adopt the conference culture (termed "tourists"), those who turn away from the home culture and fully adopt the conference culture (termed "expatriates"), and those who are "learners" by acknowledging dual membership held in "both the home culture and that of the conference and who [are] open to the conference while maintaining some distance and critical capacities" (p. 10).

To explore what and how learning occurred for participants of a human resource development (HRD) conference, Hatcher, Wiessner, Storberg-Walker, and Chapman (2006) conducted a qualitative case study. Data consisting of 1000 "new learning" forms were analyzed, resulting in the emergence of findings under three overarching categories/themes - namely, critical perspectives on HRD as a discipline, relationships between theory and practice, and learning in organizations. Participants indicated that discussion and dialogue, as well as a critical perspective related to the conference content, were crucial to their learning. They also found that "pre-conference workshops, symposia and informal individual reflections" (p. 268) proved to be the most common venues informing participant learning while at conferences. They highlighted the issue of time constraints at the conference as a significant challenge to learning noting that "time for reflection is often lacking in conference settings and should be planned in order to foster an environment 
conducive to learning" (p. 268). Correspondingly, Wiessner, Hatcher, Chapman, and StorbergWalker (2008) investigated an evaluation intervention used to enhance the output of attendees' post-conference learning. Rather than focusing conference evaluation methods on event planning and facilitation feedback, they focused conference evaluation methods on learning in order to help attendees reflect on their new theoretical understandings, the quality of processes and influences of contexts on their fields, and on awareness-level knowledge gains, including connections between theory and practice.

Research on student learning in conferences has primarily been conducted at the undergraduate level. Perhaps one of the strongest evidences/supports of conferences as a significant student learning experience in the U.S. was outlined in Larkin's (2014) study of the use of a student conference as a model for authentic assessment in a second-level physics college course. Learnerparticipants at the university were required to prepare a conference paper (including abstract, first, second, and final draft for publication in the conference proceedings), then present it at a class conference at the end of their semester. Findings indicated that this model (a) allowed access to students' learning (and enhancement of learning) throughout the entire writing experience; (b) offered access to critical feedback on written and oral presentations from multiple sources including peers and instructors; and (c) "provided students an opportunity to demonstrate, at a deeper level, their understanding of [the content] while simultaneously providing them with a learning experience that would serve them well, long after the semester came to an end" (p. 45).

A few international studies have also provided insights into undergraduate student learning at conferences. These studies from Australia (Freudenberg, Brimble, Vyvyan, \& Corby, 2008), the United Kingdom (Worsley, 2003), and Latvia (Malinovska, 2012) each indicated that student participation and presentation at conferences led to increased self-confidence/self-efficacy and high levels of meaningful feedback. In addition, Worsley's (2003) study investigated the use of a geography mini-conference that found participation fostered a sense of well-being and pride and encouraged preparedness for oral presentation (the latter, fueled by 'the fear factor' and a desire to do well, given the presence of outside/industry personnel). Second, conference participation stimulated "links between students and local external agencies" (p.76), while situating content learning in a more tangible and 'real world' context. Third, students received the opportunity to discuss future research possibilities through informal discussions and networking with peers and external participants. Finally, Malinovska (2012) found that conferences provided multiple learning and development opportunities for undergraduate Latvian students majoring in English. Data gathered from student interviews revealed that participation in the international conference helped them to enhance their foreign language and cross-cultural communication skills, provide networking opportunities with collegiate peers, increase their ability to work independently, and overcome stress in speaking a foreign language to large gatherings.

In examining participation in graduate student conferences, Kim, Lee, and Choi (2010) found that students appreciated opportunities to partake in conference experiences, but the availability of research and travel funding were "strong motivational factors for research completion and conference participation" (p. 83). Likewise, Chapman et al. (2009) examined doctoral student participation and learning processes within the context of a HRD conference and found that "expectations, approach and personal characteristics" all impacted the participants' conference experiences (p. 16). Specifically, although students experienced more barriers than bridges to learning about the scholarly community, they consistently cited networking with others who had shared interests as important in their conference learning experiences. This, the researchers explained, gave students ready opportunities for continued participation and allowed them to begin "to understand the nature of scholarly discourse" (p. 15). However, participants cited a lack of time and space for interaction as a key barrier to their learning processes at the conference. Still, Hall and Burns (2009), in their discussion of identity and mentoring in doctoral education, caution that 
more informal extra-curricular experiences such as workshops and other activities critical to identity development are peripheral to doctoral student experiences and might be limited on their own. They argue that explicit researcher identity development should also take place via strategic and formal curriculum design.

\section{Theoretical Framework}

Because we believe that context characterizes and influences learning, situated cognition frames this study. Collins (1988) defined situated learning as "the notion of learning knowledge and skills in contexts that reflect the way the knowledge will be useful in real life" (p. 2). Interaction and participation in social contexts, therefore, are the means by which learners can become actively immersed in a community of practice (Lave \& Wenger, 1991). A community of practice $(\mathrm{CoP})$ is defined as "a group of people who share an interest in a domain of human endeavor and engage in a process of collective learning that creates bonds between them" (Wenger, 2001, p. 2339). CoPs are rooted in the constructivist paradigm which advocates for a non-traditional learning environment that values authentic problem solving, collaboration, and shared goals. Additionally, a CoP has the following distinctive features: (1) a domain - so that community members are knowledgeable of or competent in an area or focus; (2) a community - involving joint activity, discussion, sharing, and helping; and (3) a practice - the space in which participants share a hub of resources that may include experiences, stories, tools, and solutions to recurring challenges that exist in the domain (Wenger, 1998). Members of a CoP include experts and novices of varying levels of experiences, skills, and professional competencies. CoP members are considered legitimate peripheral participants (Lave \& Wenger, 1991), in which their participation occurs "within specific socio-cultural contexts where various histories and intersections of individual and community differences exist" (Teeuwsen, Ratcovic, \& Tilley, 2014, p. 683). Legitimate peripheral participation can be empowering or disempowering depending on whether it facilitates or prevents participation or interchange among communities of practice (Lawless, 2008; Teeuwsen et al., 2014).

Learning within a $\mathrm{CoP}$ is the process by which members develop an identity, while simultaneously acquiring the skills and knowledge that are being shared. Learning, then, should not be viewed as separate from other activities such as work, play, or other social interactions. Cognitive apprenticeships often occur in CoPs, as they focus learning in activity and provide expert-guided assistance in authentic problem-solving experiences (Brown, Collins, \& Duguid, 1989). It is only through these experiences and practices that new members can assume a new identity (with attendant attitudes, behaviors, and values) and ultimately become full members of the community. Newcomers may participate in a community through observation, while other participants might engage in diverse interactions. Therefore, membership participation is voluntary, and the success of learning and growth within CoPs is dependent upon member interactions and a sense of aliveness which requires energy (Wenger, McDermott, \& Snyder, 2002). This energy, which underpins participation, interaction, and learning, is driven by excitement and perceived relevance/value to the community's members.

In considering the field of adult higher education, we know that adult students who attend higher education are located within multiple CoPs across their experiences, and it is the meaning that these adults construct in the higher education environment that can influence their successful, or unsuccessful, participation (O'Donnell \& Tobell, 2007). We also noted in the literature reviewed earlier that in doctoral programs students learn about research through a variety of situations including coursework, extensive critical consumption of the literature, and interactions with instructors and academic peers, and through attending and participating in research conferences. Correspondingly, researchers have recently considered communities of practice as appropriate in describing and framing their research on learning in such events (Hilliard, 2006; Jacobs \& McFar- 
lane, 2005; Weissner et al., 2008). For example, Hilliard (2006) suggests that, conceptually, communities of practice can establish a new learning model for conferences interested in integrating adult learning principles. Others indicate "conferences offer one way for those who are inexperienced to mix with the established members of the community and take part in the business of being a professional researcher" (Jacobs \& McFarlane, 2005, p. 319).

Because the research has additionally shown that doctoral students learn significantly through informal mentoring and relational processes, the current study is also framed in informal and incidental learning theories. Marsick and Watkins (2001) describe the core characteristics of informal learning as "a category that includes incidental learning, is not typically classroom based or highly structured, and consists of learning that is heavily controlled by the learner" (p. 25). Further, they explain that:

Formal learning is typically institutionally sponsored, classroom-based, and highly structured... Incidental learning is defined as a byproduct of some other activity, such as task accomplishment, interpersonal interaction, sensing the organizational culture, trial-anderror experimentation, or even formal learning. Informal learning can be deliberately encouraged by an organization or it can take place despite an environment not highly conducive to learning. Incidental learning, on the other hand, almost always takes place although people are not always conscious of it. (Marsick \& Watkins, 1990, p. 12)

These theorists contend that adult educators can provide a structure within which learners identify conditions in their socio-cultural contexts that might help them gain more insight, question perceptions/viewpoints, or interpret situations appropriately in social/group settings. As well, they have explicitly linked informal and incidental learning to learning of others and to Lave and Wenger's (1991) CoPs (Marsick \& Watkins, 2001).

\section{Method}

\section{Study Context}

A doctoral student research forum appended to a national education convention was the setting of the current research. Doctoral students at all levels of their programs were invited to participate in a 7-hour day of student research poster presentations and mentoring roundtables with academicians, professionals, and other doctoral students. Participants were encouraged to present their dissertation or other research projects at various stages of the research process. The mentoring roundtables offered an opportunity for members of the professoriate, as well as other professionals who had completed their doctoral work, to meet with students in a casual atmosphere to discuss their own research, methodologies, and various insights into the job market and university expectations. Through extensive marketing to various listservs and programs around the country and the world, the forum accepted over 60 student presentations, each year, for two consecutive years.

\section{Data Gathering}

Similar to Wiessner et al.'s (2008) study that utilized an evaluation intervention to investigate conference participant learning, the inquiry in this study focused on understanding how the participants' experiences at the forum played a part in their understanding of doctoral study, of research, and of the community of academic practitioners in their discipline. This information was sought to help forum coordinators learn how they might better design and organize future forums and other similar experiences. As such, data were gathered from a sample of convenience via a post-forum, confidential online questionnaire. A cross-sectional survey design approach was chosen since this design is often used to help describe events, experiences, and outcomes so that edu- 
cators can plan for necessary change (Fink, 2009). Open-ended questions were drafted to elicit qualitative data responses to provide a space for students' reflective voices. These questions were then reviewed and revised by a panel of experts that included qualitative educational researchers and doctoral program faculty. Our focus in this review process was on the design's ability to produce credible, context-embedded, dependable, and confirmable data for analysis (Lincoln, 1995). The study was then approved by the Institutional Review Board from the principal investigator's university.

The questionnaire was placed on a secure website on the Internet, and individuals who attended the forum were sent an invitation via e-mail to participate. An information sheet describing the study with contact information for the principal investigator was attached to the invitation e-mail. Study recruitment requests were sent to 140 forum participants, and the online questionnaire was available for one month after the initial email requests for participation. Fifty-three people volunteered and responded to the questionnaire for a $30.1 \%$ overall response rate. Participants were diverse and hailed from 15 different countries in 38 institutions. Eighty-seven percent $(n=44)$ of the respondents were student presenters, and their data were analyzed for this study. The questionnaire asked respondents to comment on what they had learned (if anything) through presenting and interacting with other doctoral students, professors, and professionals while participating at the forum. Table 1 indicates the following questions and number of responses that were analyzed:

Table 1. Questions and Corresponding Number of Responses

\begin{tabular}{lc}
\hline \multicolumn{1}{c}{ Question } & \# of Responses \\
\hline "If you presented at the Forum, was this of benefit to you? If yes, in what & 41 \\
way?" & 39 \\
"What did you find most challenging about presenting at the Forum?" & 36 \\
"What, if anything, did you learn from the experience of presenting at the Fo- & 39 \\
rum this year?" & 33 \\
"What (if anything) did you learn from other participants this year?" & \\
"What (if anything) did you learn during your experiences at the Forum about & 34 \\
"We dissertation process?" & \\
about (if anything) did you learn from interacting with the others at the Forum & \\
\hline
\end{tabular}

\section{Data Analysis}

The response data were analyzed via constant comparison methods (Glaser \& Strauss, 1967) across the completed questionnaires. First, the researchers read and re-read through each participant's responses to get an overall sense of the data. Data were then broken down into a list of codes which offered us analytic scaffolding upon which to build our analyses (Charmaz, 2000). Guided by our research questions, the research team initially developed codes individually by identifying short chunks of participant responses that offered insight into their learning experiences at the forum. Subsequently, we compared our coding by collectively searching for patterns across these codes to discover what was noteworthy and meaningful. We then used crossparticipant analysis by grouping answers to each question to examine various perspectives on specific topics (Patton, 1990). By consistently comparing the codes within each question's responses, and then across the responses for all the questions, we could finally group the codes into 
a compilation of categories and eventually subthemes. Table 2 provides an overview of this stage of the analysis process.

Table 2. Cross-Participant Analysis Table

\begin{tabular}{|c|c|c|}
\hline Category & Description & $\begin{array}{l}\text { Number of occur- } \\
\text { rences in the data }\end{array}$ \\
\hline \multicolumn{3}{|c|}{ Subtheme: Practice interacting in professional dialogue } \\
\hline $\begin{array}{l}\text { Value of informal, authentic } \\
\text { comparative examinations of edu- } \\
\text { cation research processes }\end{array}$ & $\begin{array}{l}\text { Learned through the opportunity to share } \\
\text { research with interested student peers and } \\
\text { experts which helped develop new } \\
\text { knowledge about research pro- } \\
\text { cess/research design/data analyses/writing } \\
\text { up of research }\end{array}$ & 22 \\
\hline Networking skills & $\begin{array}{l}\text { Learned how to participate in the research } \\
\text { field through interacting with established } \\
\text { and emerging scholar communities }\end{array}$ & 21 \\
\hline $\begin{array}{c}\text { Emotional outcomes of interac- } \\
\text { tion }\end{array}$ & $\begin{array}{c}\text { Interactions led to the realization of a } \\
\text { shared experience and to renewed motiva- } \\
\text { tions to persist to completion of doctoral } \\
\text { program }\end{array}$ & 13 \\
\hline \multicolumn{3}{|c|}{ Subtheme: Practice in presenting one's own research to others in the field } \\
\hline $\begin{array}{c}\text { Preparing to articulate one's re- } \\
\text { search }\end{array}$ & $\begin{array}{c}\text { Experience creating a presentation of } \\
\text { one's own research at various stages of } \\
\text { the investigation required preparation and } \\
\text { planning }\end{array}$ & 12 \\
\hline $\begin{array}{l}\text { Practice presenting and discuss- } \\
\text { ing one's research }\end{array}$ & $\begin{array}{l}\text { Opportunity to share research projects } \\
\text { with interested student peers and experts }\end{array}$ & 12 \\
\hline Value of critical feedback & $\begin{array}{l}\text { Receiving and valuing critical feedback } \\
\text { from experts and peers. }\end{array}$ & 11 \\
\hline $\begin{array}{c}\text { Presenting in a low-risk, "safe" } \\
\text { environment }\end{array}$ & $\begin{array}{c}\text { Increased self-efficacy in professional } \\
\text { presentations }\end{array}$ & 10 \\
\hline
\end{tabular}

Further analyses of the subthemes led to the establishment of larger, overarching themes that make up the structure of our findings.

\section{Findings}

Data analyses provided valuable insight into the emotional and intellectual complexity of doctoral study and of becoming an education research scholar. With regard to the ways participating in a research forum impacted these learners' understanding of research and of the community of scholarly practice, participants suggested that the opportunity to present and discuss their research 
and to exchange ideas and experiences about doctoral study with peers, professors, and professionals outside of their home university was invaluable to their development as researchers. Specifically, data analyses suggested that their presentations and interactions at the forum offered important insight into the research process as well as into participation in the larger scholarly professional community of practice in their own discipline. Respondents indicated they learned important nuances about research design, analyses, and writing processes, and they also acknowledged that complications arise regularly and are a normal occurrence throughout the life of a research project. They also recognized the benefits of 'practicing' one's interaction skills in a professional, yet safe and informal setting.

\section{Enhanced, Nuanced Insights about Research and the Community of Scholarly Practice}

Our participants indicated they gained meaningful insights about research and the scholarly CoP through both the preparation process for and through practice experiences of professional academic research presentations and dialogue. Learners who were in various stages across the lifespan of the dissertation experience indicated that in planning to present one's research, authentic presentation preparation and planning skills were practiced in order to learn and master the articulation of both the product and the process. Learning about what to prepare, and then actually preparing for presentation provided participants opportunities to practice the scholarly tradition of research presentation. One participant suggested, "Preparing my poster helped me think about my research from different angles and see how best to present the data and theories for an outsider to understand." Another offered, "I had to go through 'that process' that presenting one's work forces one to go through (e.g., turn an idea into a coherent statement of some sort)."

Creating the poster and preparing the verbal explanation of their research also helped novice presenters "think about [their] work in new ways," "to work out the kinks" in the demonstration and articulation of their research in a manner they had not experienced previously in their academic programs. For some it provided practice for their upcoming proposal or full dissertation defenses (e.g., "It helped me organize my ideas, prepare for my dissertation defense"), while others asserted that preparing for the presentation provided new insight into "how to meet the requirement of the audience" when discussing research.

Subsequently, actually presenting their work in the poster format afforded participants multiple opportunities to practice their presentation and delivery skills. New understandings of the research process were developed in the discussions that ensued in each reiteration of the presentation. Sharing one's work with others was found to be both enriching and affirming. One respondent offered, "I learned that sharing research is valuable personally and universally," while another asserted, "The chance to share ideas and communicate with other novice researchers was invaluable." These focused, yet informal discussions offered invaluable practice in professional dialogue which assisted participants in gaining essential professional oral skills in talking about their own research. Comments such as, "Sharing helps you articulate your research," and "I [met with] people interested in the same topic, and [I learned] I could discuss my research with them" were echoed throughout the data. As well, others offered that presenting their work helped to develop their own thinking about their research and the stages in which they currently inhabited. One submitted, "Presenting helps with the overall analysis of data," and another suggested, "Through discussing my project with others informally, I got some new ideas that can help me develop this [the dissertation research] more and think about future projects....I learned the value of an informal venue in which to share research with fellow scholars in the field."

The poster presentations also proved to be an "invaluable" opportunity "to share ideas and communicate with other novice researchers." Participants indicated that the stories that were shared across these professional dialogues offered important practical insight into the complexities of 
education research, as is demonstrated in this response, "The valuable piece that gets shared in this forum are the stories that accompany the research, for example, dealing with ethics review boards, losing data, different research approaches, when to take a break, etc." The dialogue that occurred during presentations offered participants constructive and often nuanced feedback on their research and the research process. Examples include responses such as, "the comments and feedback I gained from the audience were extremely beneficial to me in improving my research," and "I received a lot of valuable advices from other doctoral students as well as many professors in [our] field. They helped me to sharpen my ideas and address some questions in my mind." Another offered, "I got useful insights in how to conduct my study. I also was able to see which areas need more explanation." The poster presentations were often these learners' first chance to talk about their research, and about others' research, in a venue that offered many interested discussants who were familiar and genuinely interested with the academic discipline and research (other than the professors who were on their dissertation committees).

The practice and value of networking, a key requirement in many scholarly communities of practice (Hilliard, 2006), as well as receiving critical feedback on one's research, comprised a subtheme in answering our first research question. Participants explained the value of "talk[ing] to other doctoral students in a friendly low-risk kind of environment," and that throughout the day they "had great conversations." Comments such as these highlight the value participants realized in the professional social interactions: "the networking was the best!", "I made connections and networked with people who were interested in my research", and "I met so many other students and professors. They had so many resources to refer to me. It was definitely one of the highlights from the conference." Networking was also characterized as gaining support from other novices in the field, as is evidenced in this response, "I had the chance to meet colleagues and faculty and receive feedback -and most important- support from them. It was an intellectually challenging meeting where I learned a lot from fellow [doctoral students]." Others found that networking offered them different understandings of their field, as is evidenced in this response,

The Forum gave me a huge opportunity to meet with $\mathrm{PhD}$ students from all across North America. I would not have had this chance to meet such a wide diversity of people studying for their PhD's without the forum. I was able to exchange ideas with PhD students from other institutions besides my own, and to see what they are researching, and how my research fits into what is currently going on across North America.

The chance to network through presentations with peers, professors, and professionals from multiple institutions from across the country (and the world) in similar programs offered them insights into the diversity of the field, and where their own research fit within it, that they had not previously understood.

\section{Participation as Confidence-Building and Motivational: "It Can Be Done!"}

In answering our second research question regarding the nature of participatory learning within the forum, respondents revealed that the forum's format offered a "low-risk," "informal," and "safe" environment in which to interact in authentic professional dialogue. One participant offered, "I met a lot of people whose interests overlapped with mine, so it was a fantastic and laid back networking experience." Another indicated "The forum additionally gave me the chance to present in a safe environment to my peers. I was inspired by the other presentations and felt a little less lonely as a PhD student."

The informality and safety of the experience, as well as the opportunity to present one's research multiple times, aided in participants gaining confidence in their own work, as well as in their ability to interact competently in scholarly conversations. Excerpts such as these help illustrate this 
finding: "I just felt more comfortable after giving my talk several times. It was a good confidence booster. It helped with the 'professionalization' of doctoral students and socializing in the academic world," and ,

I was able to know what and where I was as a PhD student. Actually, I could not believe that I knew much more than I thought and was able to discuss research and topical issues with other presenters with confidence.

Others indicated that preparation and presenting at the forum helped them identify how much they had achieved thus far in their doctoral studies,

The Doctoral Forum is a wonderful way for me to focus on what I have achieved so far in my research study. I am in the middle of my data collection at the moment, but in order to produce my poster, I ran some analyses of my data. Making the poster was a chance for me to test out my ideas and confirm that I am on the right track with my data collection. It focused my thinking and helped to build my confidence.

Finally, one respondent suggested that although "It is somewhat 'normal' to be constantly doubting yourself, [we have to] keep plugging away and our confidence will emerge along the way." It was clear that having occasions to practice presenting, professional dialogue, and networking in ways that tap into the realities of these skills in a scholarly community of practice helped to build confidence along the pathways of doctoral study.

Ultimately, participants overwhelmingly indicated the benefit and importance of sharing experiences of doctoral programs and research with others. These informal conversations emerged throughout the forum - throughout the poster sessions, at breaks, and at lunch. These conversations resulted in our respondents realizing that they were not alone on their doctoral studies journey, nor in the emotions and doubts they experienced. They also believed these important dialogues offered practical advice and led to renewed motivations to persist. One participant suggested,

The dissertation process is an on-going research process, a partial fulfillment of the requirement of the doctoral program. Listening to the sharing from other doctoral students helped me realize the difficulties they experienced and the support they needed. Their experiences offered invaluable guidance for me!

Another indicated, "I felt supported and very much part of a special cohort." Others submitted that talking with others about each other's dissertation research offered important awareness of the likeliness of problems that would arise. They stated, "It was nice to listen to people who are farther in their plans of study tell us about some of the difficulties they have experienced," that "if something can go wrong, it will!", but "that good dissertation planning can help avoid wasted time and other "unforeseens." Ultimately, participants summarized that they "learned that the process is arduous... but [we] got a lot of tips and how to keep going and survive writing a dissertation." Respondents learned at the forum that their research would be difficult and complex essential recognition of the realities of the academic life. But they did not leave discouraged. In fact, they indicated they were encouraged and highly motivated to persevere and continue toward completion of their work. Responses such as these help to illustrate this finding: "Like anything else, the dissertation process is just that, a process. It takes time and there may be hurdles and challenges along the way, but eventually, with perseverance, the dissertation will be completed;" "I am inspired a bit more to finish my data interpretation and write Chapters 4 and 5;" and "That it is long but rewarding. The dissertation process quenches the researcher's thirst for knowledge and transcendence." Learning of others' struggles and successes, and realizing "I am not ALONE," aided participants in overcoming some of their doubt and frustrations. Indeed, many left believing, "It can be done!" 


\section{Discussion and Implications}

We found that students' reflective voices provide educators access to learning perspectives, backgrounds, and developing experiences with research. These, in turn, can shape how methodology courses, supervision, support programs, and research conferences can be more effectively designed for developing researchers. The doctoral student forum provided a unique collegial space for doctoral students from around the world to gather for the purpose of discussing research, the dissertation process, and the doctoral student experience. Participation in the forum was characterized as gaining access to simulated practice in professional interactions. Participants valued the interfaces that included informal comparative examinations about the research process, design, analyses, and writings. And, they learned through interacting within a community of scholarly practice that extends beyond the limitations of the home institution.

For some of our respondents, this was their first introduction to the scholarly educational community at large. Just as writing is "a way of knowing, a method of discovery and analysis" (Richardson, 1994, pp. 516-517), we found that the self-reflective experience of preparing and presenting/discussing one's study at various stages of the research process was also a way of knowing and analysis. Learning about and practicing the professional socialization processes required of participants in research conferences became paramount in understanding what our respondents found most meaningful in their learning at the forum. As developing researchers, the learning activities involved in presenting at the forum seemed to have provided a structure that helped support their examinations and re-examinations of their thought-processes as professional researchers (Mittapalli \& Samaras, 2008). In preparing for, presenting, and interacting at the forum, students found their capabilities and their roles of participation (Jorgensen, 1989) were stretched and extended, re-molded, and enriched. Through this practice, participants had to confront faceon what they knew and what they needed to know. The learning occurred as they rehearsed, they exercised, and they interpreted professional dialogue and interaction in ways that were different from practice experiences afforded them in their doctoral programs. We argue that these enhanced comprehensions of research, and a deeper awareness of self-as-scholar, are both required for membership and participation in the professional $\mathrm{CoP}$ of education researchers.

The informal nature of the forum also provided a safe environment in which to put oneself and one's work into the public eye of peers and professionals. Analysis showed that participants found a comfort in recognizing the familiar stories and experiences expressed by the forum's students and mentors. These stories helped the students to realize that they were not alone in their periodic anxiety, misgivings, and frustrations while learning about and doing educational research. The whole of their experiences, which included their presentations and dialogue during presentations, at breaks, and at the mentoring roundtables also offered the opportunity to peer into the research process and doctoral study from the outside-in, rather than from only the often lonely, inside-out. As such, our respondents evoked an understanding of the dependence and interdependence between the CoPs of their doctoral studies and that of the professional CoP. Figure 1 graphically depicts the connections among the overlapping communities, developmental experiences, and professional practices within which the participants learned and worked. 


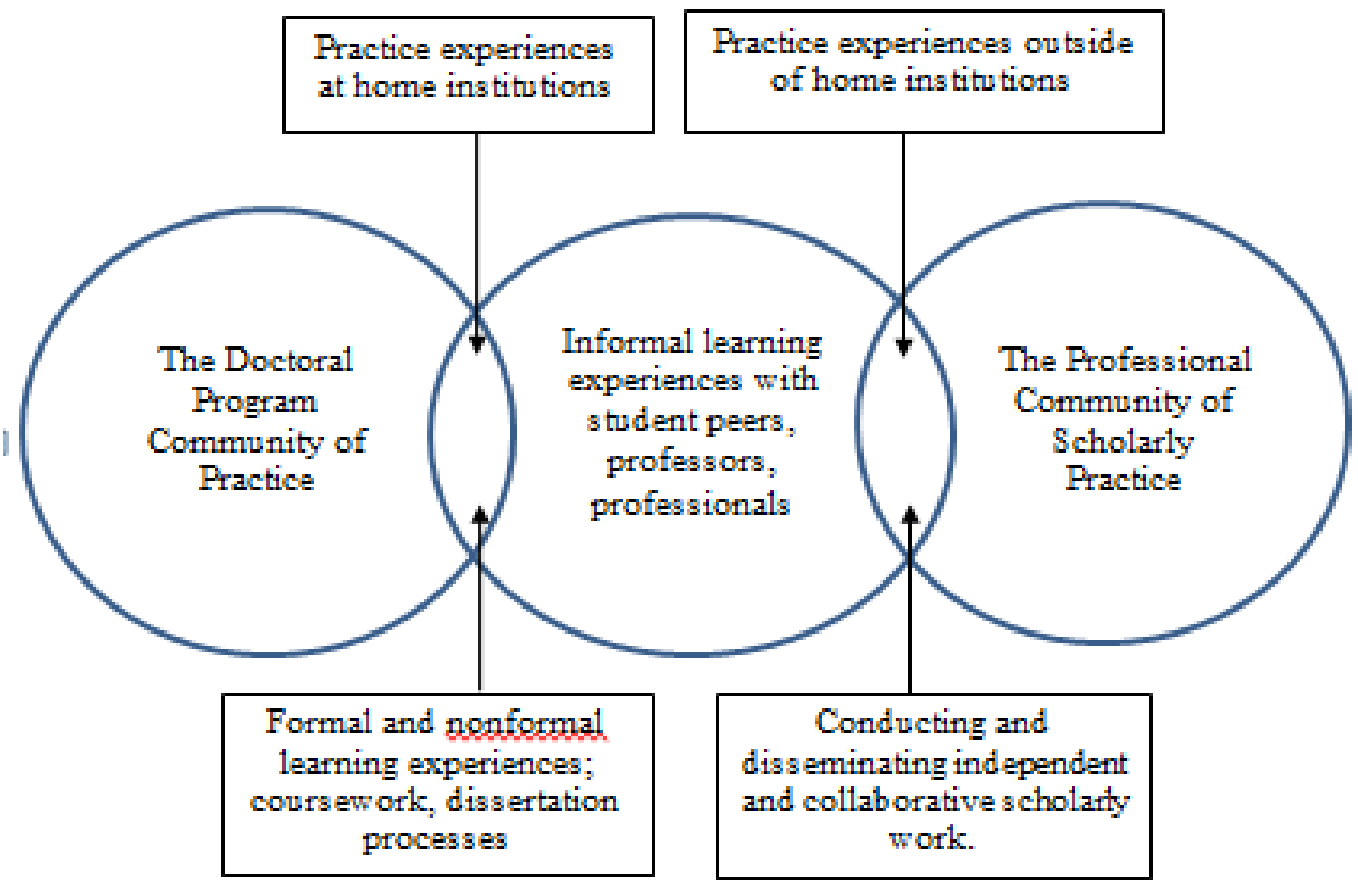

Figure 1. Relationships of Overlapping Communities of Practice in Doctoral Education. Adapted and expanded from Coryell (2011).

Many acknowledged the importance of learning to situate their own learning journeys and their dissertation research into a wider professional context. Calling upon their learning and practice experiences at their home institutions, they enacted necessary socialization processes (i.e., research presentation and discussion exchanges, critical analyses of personal and others' research, informal dialogue and debate rooted in the discipline) that aided in identifying the individual agency and interaction required for full participation in the scholarly community. In the course of the experience, participants believed they got a glimpse of where they were going and where they wanted to arrive in the profession. They gained a better sense of what they needed to get there, and ultimately, like previous research on student learning in conferences (Freudenberg et al., 2008; Malinovska, 2012; Worsley, 2003), their self-confidence and self-efficacy were enhanced.

Green (2005) suggested doctoral supervision should be understood as a pedagogic practice. Our research extends this pedagogy by suggesting a combination of formal and informal experiences were specifically supportive of doctoral students' professional development at the forum. As such, we recommend that advisors, faculty, and administrators design and support opportunities for doctoral students to interface with multiple facets of academic and professional CoPs as supplemental experiences to their formal doctoral programs. We found that a doctoral research forum appended to a larger professional organization convention was a meaningful and successful experience for our participants in their professional development. But, we can also envision that smaller, local or regional forums would likewise be extremely useful - as long as networking and dialogue were included in the planned learning processes in these events. As well, our findings suggest the importance of designing space and time for students to discuss the ups and downs of doctoral study. These discussions need to be hosted in an environment that is explorative and intellectually-focused, supportive, and nonjudgmental. We also propose inviting students and professors from other programs to participate.

Additionally, this investigation found that students need opportunities to present before the completion of their dissertation project. Participants highlighted the positive impact of presenting at various stages of dissertation research development, noting that it required them to think about 
and discuss their work in different ways than they had before presenting. We also recommend offering opportunities for students to prepare and present dissertation work in poster sessions and/or roundtable presentations, along with more formal paper presentations, in order to develop a variety of thought-processes and presentational, dialogic, and interactional skills necessary in scholarly discourse and dissemination.

Limitations for this study include that it was a sample of convenience, that we collected responses at just one forum (albeit over two years), and that the study was limited to a sample of education doctoral student participants. As is standard for qualitative research, we also do not claim that results are representational across all doctoral students' experiences at research conferences. Indeed, we believe more studies need to be conducted to identify how other disciplines understand their own communities of scholarly practice and the ways in which their programs may help to develop the bridges necessary for graduates to gain access to them. As well, Hilliard (2006) contends that conference or forum organizers should "design and promote educational content to appeal to prospective attendees," but must also "look further to determine what motivates people to attend conventions and learn" (p. 49). Likewise, further studies focused on conference offerings and learning opportunities that are specifically meaningful for doctoral students and emerging scholars are also warranted. Finally, in this study roughly $40 \%$ of the participants suggested they would not have been able to secure funding to attend the national convention without having been accepted to present at the forum. Consequently, we advocate for national and regional educational professional organizations to coordinate and support doctoral student forums that can be appended to the larger convention/conference. Doing so may potentially increase overall conference participation and provide excellent professional interactional experiences with scholars outside of the home institution for doctoral students to situate themselves and their work in the larger scholarly community.

\section{References}

Astramovich, R. A., Okech, J. E., \& Hoskins, W. J. (2004). Counselor educators' perceptions of their doctoral coursework in research methods. Guidance \& Counseling, 19(3), 124-131.

Austin, A. E. (2002). Preparing the next generation of faculty: Graduate school as socialization to the academic career. The Journal of Higher Education, 73(1), 94-122.

Borg, S. (2001). The research journal: A tool for promoting and understanding researcher development. Language Teaching Research, 5(2), 156-177.

Brown, J. S., Collins, A., \& Duguid, P. (1989). Situated learning and the culture of learning. Education Researcher, 1(1), 32-42.

Chapman, D. D., Wiessner, C. A., Morton, J., Fire, N., Jones, L .S., \& Majekodunmi, D. (2009). Crossing scholarly divides: Barriers and bridges for doctoral students attending scholarly conferences. New Horizons in Adult Education and Human Resource Development, 23(1), 6-24.

Charmaz, K. (2000). Grounded theory: Objectivist and constructivist methods. In N. K. Denzin \& Y. S. Lincoln (Eds.), Handbook of qualitative research (2nd ed., pp. 509-535). Thousand Oaks, CA: Sage.

Collins, A. (1988). Cognitive apprenticeship and instructional technology (Technical Report No. 6899). BBN Labs Inc., Cambridge, MA.

Coryell, J. E. (2011). Insights into experiences in student research forums: The case of the TESOL Doctoral Student Forum. Proceedings of the National Conference of the Canadian Association for the Study of Adult Education/Association Canadienne pour l'Étude de l'Éducation des Adultes and the Adult Education Research Conference (pp. 140-147). Toronto, CA: Ontario Institute for Studies in Education, University of Toronto. 
Coryell, J. E., Clark, M. C., Wagner, S., \& Stuessy, C. (2013). Becoming real: Impressions of developing an educational researcher identity. Journal of Further and Higher Education, 37(3), 367-383. doi: 10.1080/0309877X.2011.645456

Donaldson, J. E., Flannery, D., \& Ross-Gordon, J. (1993). A triangulated study comparing adult college students' perceptions of effective teaching with those of traditional students. Continuing Higher Education Review, 57(3), 147-165.

Drago-Severson, E., Asghar, A., \& Gaylor, S. S. (2003). Learning qualitative data analysis in North American university: Teaching reflections on creating supports and scaffolds for researcher development. Paper presented at the annual meeting of the American Educational Research Association (Chicago, IL, April 21-25, 2003).

Fink, A. (2009). How to conduct surveys (4th ed.). Thousand Oaks, CA: Sage.

Freudenberg, B., Brimble, M., Vyvyan, V., \& Corby, D. (2008). A penny for your thoughts: Can participation in a student-industry conference improve students' presentation self-efficacy and more? International Journal of Learning, 15(5), 187-200.

Gardner, S. K. (2009). The development of doctoral students: Phases of challenge and support. ASHE Higher Education Report, 34(6).

Glaser, B., \& Strauss, A. (1967). The discovery of grounded theory: Strategies for qualitative research. Chicago: Aldine.

Golde, C. M. (1998). Beginning graduate school: Explaining first-year doctoral attrition. In M. S. Anderson (Ed.), The experience of being in graduate school: An exploration (pp. 55-64). San Francisco: JosseyBass.

Graham, S. W., \& Donaldson, J. F. (1999). Adult students' academic and intellectual development in college. Adult Education Quarterly, 49(3), 147-161.

Graham, S. W., Donaldson, J. F., Kasworm, D., \& Dirkx, J. (2000, April). The experiences of adult undergraduate students - What shapes their learning? New Orleans, LA: American Educational Research Association. (ERIC Reproduction Document Service No. ED440275).

Green, B. (2005). Unfinished business: Subjectivity and supervision. Higher Education Research \& Development, 24(2), 151-163.

Grover, V. (2007). Successfully navigating the stages of doctoral study. International Journal of Doctoral Studies, 2, 9-21. Retrieved from http://www.ijds.org/Volume2/IJDSv2p009-021Grover21.pdf

Hall, L.A., \& Burns, L.D. (2009). Identity development and mentoring in doctoral education. Harvard Educational Review, 19(1), 49-70.

Hatcher, T., Wiessner, C., Storberg-Walker, J., \& Chapman, D. (2006). How a research conference created new learning: A case study. Journal of European Industrial Training, 30(4), 256-271.

Hilliard, T. W. (2006). Learning at conventions: Integrating communities of practice. Journal of Convention and Event Tourism, 8(1), 45-68. doi:10.1300/J452v08n01_03

Hockey, J., \& Allen-Collinson, J. (2005). Identity change: Doctoral students in art and design. Arts and Humanities in Higher Education, 4(1), 77-93.

Jacobs, N., \& McFarlane, A. (2005). Conferences as learning communities: Some early lessons in using "back-channel" technologies at an academic conference - distributed intelligence or divided attention? Journal of Computer Assisted Learning, 21, 317-329.

Jorgensen, D. (1989). Participation observation: A methodology for human studies. Newbury Park, CA: Sage.

Kasworm, C. (2003). Adult meaning making in the undergraduate classroom. Adult Education Quarterly, 53(2), 81-98. 
Kegan, R. (1994). In over our heads: The mental demands of modern life. Cambridge: Harvard University Press.

Kim, H., Lee, D., \& Choi, E. (2010). Research activity at the annual graduate student research conference in hospitality \& tourism. Journal of Teaching in Travel \& Tourism, 10, 75-85. doi:10.1080/15313220903559262

Larkin, T. (2014). The student conference: A model of authentic assessment. International Journal of Engineering Pedagogy, 4(2), 36-46.

Lave, J., \& Wenger, E. (1991). Situated learning: Legitimate peripheral participation. New York: Cambridge University Press.

Lahenius, K. (2012). Communities of practice supporting doctoral studies. The International Journal of Management Education, 10, 29-38.

Lawless, A. (2008). Action learning as legitimate peripheral participation. Action Learning: Research \& Practice, 5(2), 117-129. doi:10.1080/14767330802185632

Leshem, S. (2007). Thinking about conceptual frameworks in a research community of practice: A case of doctoral programme. Innovations in Education and Teaching International, 44(3), 287-299.

Lincoln, Y. (1995). Emerging criteria for quality in qualitative and interpretive research. Qualitative Inquiry, 1(3), 275-289.

Lovitts, B. E. (2001). Leaving the ivory tower: The causes and consequences of departure from doctoral study. Lanham, UK: Rowman \& Littlefield Publishers.

Malinovska, L. (2012). Development of engineering student skills and competencies through participation at international scientific conferences. Proceedings of the $11^{\text {th }}$ Annual Engineering for Rural Development - International Scientific Conference, Jelgava, Latvia.

Marsick, V. J., \& Watkins, K. E. (1990). Informal and incidental learning in the workplace. New York: Routledge.

Marsick, V. J., \& Watkins, K. E. (2001). Informal and incidental learning. New Directions for Adult and Continuing Education, 89, 25-34.

Merton, R. (1957). Social theory and social structure. New York: Free Press.

Mittapalli, K., \& Samaras, A. P. (2008). Madhubani art: A journey of an education researcher seeking selfdevelopment answers through art and self-study. The Qualitative Report, 13(2), 244-261.

Nettles, M. T., \& Millett, C. M. (2006). Three magic letters: Getting to Ph.D. Baltimore: The Johns Hopkins University Press.

O'Donnell, V. L., \& Tobbell, J. (2007). The transition of adult students to higher education: Legitimate peripheral participation in a community of practice? Adult Education Quarterly, 57(4), 312-328.

Pallas, A. M. (2001). Preparing education doctoral students for epistemological diversity. Educational Researcher, 30(5), 6-11.

Parsons, J., \& McRae, P. (2007). Edifying action and site-based action research. Paper presented at the $12^{\text {th }}$ Annual Values and Leadership Conference, Penn State University, September 27-29, 2007.

Patton, M. Q. (1990). Qualitative evaluation and research methods (2nd ed.). Newbury Park, CA: Sage.

Renner, P. G. (2001). Evocative narrative as educational research. Proceedings of the Adult Education Research Conference. East Lansing, Michigan: Michigan State University.

Richardson, L. (1994). Writing: A method of inquiry. In N. Denzin \& Y. Lincoln (Eds.), Handbook of Qualitative Research, (pp. 516-529). London: Sage.

Roberts, S., \& McGinty, S. (1995). Awareness of presence: Developing the researcher self. Anthropology \& Education Quarterly, 26(1), 112-122. 
Rose, A. (1992). Conferences in the 1990s - How far have we really come? Adult Learning, 4(1), 10-11.

Stevens-Long, J., Shapiro, S. A., \& McClintock, C. (2012). Passionate scholars: Transformative learning in doctoral education. Adult Education Quarterly, 62(2), 180-198.

Stewart, D. W. (1995). Developmental considerations in counselling graduate students. Guidance \& Counseling, 10(3), 21-24.

Teeuwsen, P., Ratković, S., \& Tilley, S. A. (2014). Becoming academics: Experiencing legitimate peripheral participation in part-time doctoral studies. Studies in Higher Education, 39(4), 680-694.

Weidman, J. C., Twale, D. J., \& Stein, E. L. (2001). Socialization of graduate and professional students in higher education: A perilous passage? San Francisco: Jossey-Bass.

Weissner, C. A., Hatcher, T., Chapman, D., \& Storberg-Walker, J. (2008). Creating new learning at professional conferences: An innovative approach to conference learning, knowledge construction and programme evaluation. Human Resource Development International, 11(4), 367-383.

Wenger, E. (1998). Communities of practice: Learning, meaning, and identity. Cambridge, UK: Cambridge University Press.

Wenger, E. (2001). Communities of practice. International encyclopedia of the social and behavioral sciences, 2339-2342. doi:10.1016/BO-08043076-7/00361-2

Wenger, E., McDermott, R., \& Snyder, W. M. (2002). Cultivating communities of practice: A guide to managing knowledge. Cambridge, MA: Harvard Business Review Press.

Worsley, A. (2003). Developing external links through teaching and learning in geography and environmental science: The use of the mini-conference. Journal of Geography in Higher Education, 27(1), 6978.

Wright, R. R. (2008). Research as quest: An autoethnographic exploration of embodied class, intellectual obsession, and the academy. Journal of Curriculum and Pedagogy, 5(2), Winter, 69-94.

Young, L. J. (2001). Border crossing and other journeys: Re-envisioning the doctoral preparation of educational researchers. Educational Researcher, 30(5), 3-5. 


\section{Biographies}

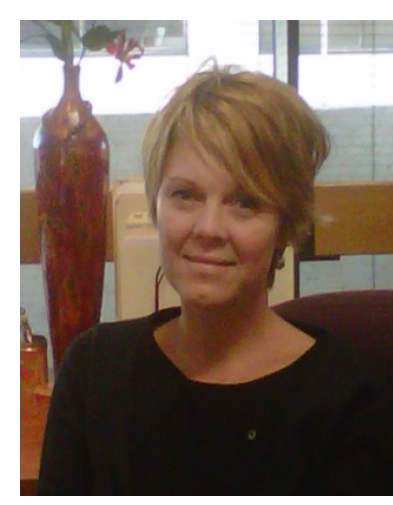

Joellen E. Coryell, Ph.D., is Associate Professor of adult, professional, and community education and Program Coordinator of the M.A. in Adult Education at Texas State University. Her research focuses on international cross-cultural adult and higher education and the investment in the professional development of adult professional and higher education educators and leaders.

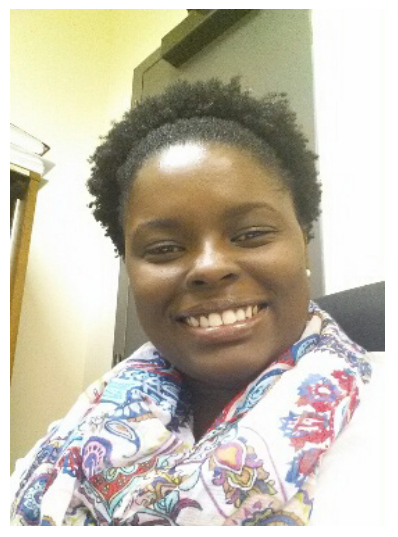

Kayon K. Murray-Johnson is a Ph.D candidate and Doctoral Research Assistant in the Adult, Professional and Community Education program at Texas State University. Her research interests include creative teaching strategies, cross-racial and cross-ethnic dialogue and immigrant learning experiences - all within the context of diverse adult and higher education settings. 